\title{
Characteristic of chronic myelogenous leukemia patients at the Polyclinic of Oncology, Dr. Soetomo General Academic Hospital, Surabaya, Indonesia in 2017
}

\author{
M. Rifqi Wiyono ${ }^{1}$, Siprianus Ugroseno Yudho Bintoro ${ }^{2 *}$, Yetti Hernaningsih ${ }^{3} \mathbb{D}$ \\ ${ }^{1}$ Medical Program, Faculty of Medicine, Universitas Airlangga, Surabaya, Indonesia, \\ ${ }^{2}$ Department of Internal Medicine, Dr. Soetomo General Academic Hospital, Surabaya, Indonesia, \\ ${ }^{3}$ Department of Clinical Pathology, Dr. Soetomo General Academic Hospital, Surabaya, Indonesia
}

\begin{tabular}{l}
\hline Article Info \\
\hline Article history: \\
Received Nov 29, 2019 \\
Revised Dec 1, 2019 \\
Accepted Dec 9, 2019 \\
Publised Jan 1, 2020 \\
\hline
\end{tabular}

Keywords:

Leukocytosis

Normocytic

normochromic anemia

Chronic myelogenous

leukemia

Thrombocytosis

Myeloproliferation

Cancer

\begin{abstract}
Background: Chronic myelogenous leukemia (CML) is a myeloproliferative neoplasm because of the reciprocal translocation of chromosome 22 to chromosome 9. In the United States, the incidence of CML is 1.9 cases per 100,000 people. Whereas in Indonesia, there is no specific national data on CML prevalence, especially regarding the clinical profile, even though the cancer cases reach 1.4 per 1,000 population. Objective: To evaluate the characteristics and clinical features of CML patients in Dr. Soetomo General Academic Hospital, Surabaya, Indonesia. Materials and Methods: This was a cross-sectional descriptive study with data from the medical records of CML patients in 2017 at Dr. Soetomo General Academic Hospital, Surabaya, Indonesia. The sample in this study was CML patients with positive Breakpoint Clusters RegionAbelson (BCR-ABL), having a minimum age of 18 years and equipped with epidemiological data, complete blood count data, and peripheral blood smear data. Results: Thirty-three patients met the study criteria. The sample was predominantly male, with a ratio of $1.06: 1$ to female patients with a median age of 40 years. Splenomegaly was found in $87.9 \%$ of the patients. The average results of leukocyte, platelet, and hemoglobin counts were $254.58 \times 10^{3} / \mu \mathrm{L}$, $557 \times 10^{3} / \mu \mathrm{L}$, and $9.55 \mathrm{~g} / \mathrm{dL}$. From the results of peripheral blood smear obtained normochromic normocytic anisopoikilo-cytosis erythrocyte $(57.6 \%)$, all patients had a profile of increased leukocytes with blast presence in $97 \%$ of the patients, and $51.5 \%$ had a profile of an increase in platelets and the discovery of giant platelets in $33.3 \%$ of the patients. Conclusion: The sample was predominantly male with the highest incidence at a younger age range of 21-30 years. The clinical characteristics showed high leukocytosis with various stage of maturation and a tendency to develop grade 2 normocytic normochromic anemia and thrombocytosis was found in the patients.
\end{abstract}

\section{Corresponding Author:}

Siprianus Ugroseno Yudho Bintoro

Department of Internal Medicine, Universitas Airlangga, Surabaya, Indonesia

Jl. Mayjen. Prof. Moestopo no. 47, Surabaya 60131, East Java, Indonesia

ugroseno@fk.unair.ac.id 


\section{BACKGROUND}

Chronic myelogenous leukemia (CML) is a myeloproliferative cell malignancy caused by abnormal hematopoietic cells due to the reciprocal translocation of chromosome 22 with chromosome 9 , resulting in Philadelphia chromosomes with BCR-ABL oncoproteins resulting in abnormal blood cell formation and triggering CML (Jabbour \& Kantarjian, 2018).

In the United States, in 2019, cancer is one of the leading cause of death after heart disease. It is estimated that around 1.7 million people are diagnosed with cancer, and of these number estimated new cases and deaths from CML are $0.5 \%(8,990)$ and $0.2 \%(1,140)$ with a 5-year life expectancy of $69.2 \%$. CML incidence is 1.9 cases of 100,000 people (Howlander et al., 2019). In Indonesia alone, the prevalence of cancer cases reaches 1.4 of 1,000 population, but there is no specific national data on CML especially about the clinical profile (Ministry of Health, Repubic of Indonesia, 2013).

Until now, the etiology of CML is unknown. The only risk factor that is known to influence the incidence of CML is exposure to ionizing radiation (Atul \& Hoffbrand, 2014). This was discussed in another studies conducted on Japanese atomic bomb victims and among the Chernobyl cleanup workers (Rohrbacher \& Hasford, 2013). Besides, CML is thought to have no association with family relationships because no increased risk of CML was found in monozygotic twins or relatives of patients. Although radiation exposure is a risk factor for CML, it is still unclear why and how certain groups of people can suffer from CML (O'Brien, Vose and Kantarjian, 2011).

CML is divided into 3 phases, namely the chronic phase, the acceleration phase, and the blast crisis phase. A small number of patients in the chronic phase will develop into a phase of acceleration and blast crisis phase. This can occur due to additional genetic changes in leukemia stem cells that can be detected by cytogenetic analysis (Shah \& Arceci, 2014). Some patients diagnosed with CML have no symptoms and are often found during routine check-ups. In the chronic phase CML, symptoms that appear are usually caused by anemia and splenomegaly that occur, such as fatigue, weight loss, malaise, and feeling full or pain in the left upper quadrant of the abdomen. Splenomegaly is found in $40 \%-50 \%$ of cases. Accelerated phase CML is usually characterized by worsening anemia, splenomegaly, and sometime other organ infiltration, whereas the CML blast crisis phase has the same picture as acute leukemia (Jabbour \& Kantarjian, 2018). Laboratory features seen in peripheral blood of CML patients may consist of anemia, thrombocytosis, leukocytosis with a shift to the left, decreased neutrophil alkaline phosphatase (NAP), hyperuricemia, and elevated serum B12 levels. While on bone marrow examination, hypercellularity and bone marrow stroma fibrosis will be found in several cases (Raharjo, 2018).

\section{OBJECTIVE}

In general, this study aimed to evaluate the clinical profile of CML patients in Dr. Soetomo General Academic Hospital, Surabaya, Indonesia. The specific objectives of this research included evaluating the characteristics of CML patients consisting of age, sex, and enlargement of the spleen, the results of a complete blood count of CML patients consisting of hemoglobin, leukocyte, and platelet counts, and the results of peripheral blood smears in CML patients consisting the profiles of erythrocytes, leukocytes, and platelets.

\section{MATERIALS AND METHODS}

This research was a cross-sectional descriptive study by reviewing secondary data in the form of medical records of new CML patients in 2017 at the Oncology Polyclinic, Dr. Soetomo General Academic Hospital, Surabaya, Indonesia. This study had received ethical approval from Dr. Soetomo General Academic Hospital, Surabaya, Indonesia committee of the health research ethics with certificate number No. 0786/KEPK/XI/2018. Samples in this study were CML patients with positive BCR-ABL that diagnosed using quantitative real-time PCR Cepheid Genexpert BCR-ABL, had the same age or more than 18 years, and were equipped with the data needed in the study. These data were epidemiological data that included age and sex, physical examination data, ie. the presence of enlarged spleen, complete laboratory blood count data including hemoglobin, leukocytes, and platelets to evaluate the occurrence of anemia, leukocytosis, thrombocytopenia, and thrombocytosis as well as peripheral blood smear data, including the profile of erythrocytes, leukocytes, the percentage of 
eosinophils, the percentage of basophils, the presence of blasts, and the profile of platelets. Patients were said to have anemia if the hemoglobin level was below $13.3 \mathrm{~g} / \mathrm{dL}$ for men and below $11 \mathrm{~g} / \mathrm{dL}$ for women and the anemia was graded based on criteria from the National Cancer Institute which is grade 1 for the lower limit of normal values up to $10 \mathrm{~g} / \mathrm{dL}$, grade 2 for $8-10 \mathrm{~g} / \mathrm{dL}$, grade 3 for $6.5-7.9 \mathrm{~g} / \mathrm{dL}$ and grade 4 for $<6.5 \mathrm{~g} / \mathrm{dL}$. Patients were said to have leukocytosis when the leukocyte count was more than $10 \times 10^{3} / \mu \mathrm{L}$. Patients were said to have thrombocytosis if the platelet count was more than $450 \times 10^{3} / \mu \mathrm{L}$ and thrombocytopenia if it was less than $150 \times 10^{3} / \mu \mathrm{L}$. The results of the study were collected and processed with Microsoft Excel 2010 application and Statistical Package for Social Sciences (SPSS) version 17.0 then presented in tabular form.

\section{RESULTS}

There were 33 patients diagnosed with CML with a positive BCR-ABL and fulfilled the established criteria. In Table 1, it can be noted that the number of males is higher than females with a ratio of 1.06: 1 . The age range in this study is 18-69 years, with the age group 21-30 years as the most frequent, and there are only $6 \%$ of patients over 60 years old. The mean age of patients was 40.63 years, with median of 40 years old. Magnification of the spleen or splenomegaly can be found in $87.9 \%$ of patients.

Table 1. Characteristics of the patients

\begin{tabular}{cc}
\hline \multicolumn{1}{c}{ Variables } & Results \\
\hline Gender & \\
Male & $17(51.5 \%)$ \\
Female & $16(48.5 \%)$ \\
Age & \\
$\leq 20$ & $1(3 \%)$ \\
$21-30$ & $10(30.3 \%)$ \\
$31-40$ & $6(18.2 \%)$ \\
$41-50$ & $7(21.2 \%)$ \\
$51-60$ & $7(21.2 \%)$ \\
$>60$ & $2(6 \%)$ \\
Mean & 40.63 \\
Median & 40 \\
Range & $18-69$ \\
Splenomegaly & $29(87.9 \%)$ \\
\hline
\end{tabular}

Table 2. Complete blood count results

\begin{tabular}{lc}
\hline \multicolumn{1}{c}{ Variables } & Results \\
\hline Hb & \\
Mean & 9.55 \\
Median & 9.3 \\
Range & $5.3-13.2$ \\
Leukocyte & \\
Mean & 254.58 \\
Median & 224.9 \\
Range & $11.51-636$ \\
Platelet & \\
Mean & 557 \\
Median & 494 \\
Range & $122-1775$ \\
Anemia & $30(90.9 \%)$ \\
Grade 1 & $10(30.3)$ \\
Grade 2 & $15(45.5 \%)$ \\
Grade 3 & $3(9.1 \%)$ \\
Grade 4 & $2(6 \%)$ \\
Leukocytosis $(>10.000)$ & $33(100 \%)$ \\
Thrombocytosis $(>450.000)$ & $18(54.5 \%)$ \\
Thrombocytopenia $(<150.000)$ & $2(6 \%)$ \\
\hline
\end{tabular}

In the results of a complete blood count before treatment, the mean and median leukocytes were sequenced at $254.58 \times 10^{3} / \mu \mathrm{L}$ and $224.9 \times 10^{3} / \mu \mathrm{L}$ with a range of $11.51-636 \times 10^{3} / \mu \mathrm{L}$; average and median platelets respectively of $557 \times 10^{3} / \mu \mathrm{L}$ and $494 \times 10^{3} / \mu \mathrm{L}$ with a range of $122-1775 \times 10^{3} / \mu \mathrm{L}$; the mean and median $\mathrm{Hb}$ was $9.55 \mathrm{~g} / \mathrm{dL}$ and $9.3 \mathrm{~g} / \mathrm{dL}$, respectively, ranging from 5.3 to $13.2 \mathrm{~g} / \mathrm{dL}$. From these results, 30 patients had anemia, 18 thrombocytosis patients, two thrombocytopenia patients, and all patients had leukocytosis as listed in Table 2.

The results of peripheral blood smear in this study were dominated by normochromic normocytic anisopoikilocytosis erythrocytes $(57.6 \%)$, all patients had a profile of increased leukocytes with blast presence in $97 \%$ of patients, and more than half of patients $(51.5 \%)$ had a profile of increased platelets and the discovery of giant platelets in $33.3 \%$ of patients which can be seen in Table 3 .

\section{DISCUSSION}

\section{Characteristics of CML patients}

In this study, the sample was dominated by men with 17 patients $(51.5 \%)$, with a ratio between men and women of 1.06: 1 . These results were lower than epidemiological studies, which have been done before, where the ratio of men is 1.2 to 1.7 . This difference can be caused by much larger sample size 
in the study (Höglund et al., 2015). Even so, our result acknowledged that CML was more common in men than women. Men are more at risk of developing CML because they have more target cells. The target cell in question is the cell of origin in the case of radiation-induced CML or sporadic cases. This study suggested that the essential cause of differences in the number of sexes was caused by differences in the number of target cells at risk for neoplastic transformation, higher risk per target cell, or both (Radivoyevitch et al., 2014).

Table 3. Peripheral blood smear results

\begin{tabular}{|c|c|c|c|}
\hline Variables & Results & Variables & Results \\
\hline Leukocyte & & Erithrocyte & \\
\hline Profile & & Normochromic, Normocytic & $4(12.1 \%)$ \\
\hline Increased & $33(100 \%)$ & Normochromic, Normocytic, Anisocytosis & $6(18.2 \%)$ \\
\hline Normal & 0 & $\begin{array}{l}\text { Normochromic, Normocytic, } \\
\text { Anisopoikilocytosis }\end{array}$ & $19(57.6 \%)$ \\
\hline$\%$ Eosinophil & & Normochromic, Normocytic, Poikilocytosis & $1(3 \%)$ \\
\hline Increased & $7(21.2 \%)$ & Hipochromic, Anisopoikilocytosis & $3(9.1 \%)$ \\
\hline Median & $3 \%$ & & \\
\hline Range & $0.1 \%-10 \%$ & & \\
\hline \%Basophil & & Thrombocyte & \\
\hline Increased & $28(84.8 \%)$ & Profile & \\
\hline Median & $4 \%$ & Increased & $17(51.5 \%)$ \\
\hline Range & $0.3 \%-22 \%$ & Normal & $15(45.5 \%)$ \\
\hline$\%$ Promyelocyte & & Decreased & $1(3 \%)$ \\
\hline Median & $11 \%$ & Giant Platelet $(+)$ & $11(33.3 \%)$ \\
\hline Range & $3 \%-24 \%$ & & \\
\hline \multicolumn{4}{|l|}{$\%$ Myelocyte } \\
\hline Median & $12.5 \%$ & Blast & \\
\hline Range & $2 \%-32 \%$ & Presence & $32(97 \%)$ \\
\hline$\%$ Metamyelocyte & & $<5 \%$ & $13(39.4 \%)$ \\
\hline Median & $7 \%$ & $5-10 \%$ & $4(12.1 \%)$ \\
\hline Range & $2 \%-20 \%$ & $>10 \%$ & $15(45.5 \%)$ \\
\hline
\end{tabular}

The mean age was 40.63 years with median of 40 years. There are only two patients $(6 \%)$ who are in the age range above 60 years. This result is in line with the results of a study conducted at Hasan Sadikin Hospital, Bandung, Indonesia, with mean age and median, respectively 41.5 years and 42 years (Sumantri et al., 2019). However, both results were still lower than the results obtained in Western countries. In Western countries, the median range varies from 56 to 66 years (Höglund et al., 2015). Another epidemiological surveillance conducted at 2014-2018 also found a significantly higher median age of 65 years old, with $51.7 \%$ of the sample being in the age range above 64 years old (Howlander et al., 2019). These results are far different from the results of studies that have been conducted in Indonesia. This difference is likely due to genetic factors and differences in sample life expectancy. Even so, our results are on par with the study conducted in Ethiopia where most patient are in the age range of 21-30 (Fentie et al., 2019).

The spleen is the largest lymphoid organ, making it susceptible to involvement with hematological malignancies such as leukemia. The involvement in question is the existence of extramedullary hematopoiesis in leukemia, which can affect the enlargement of the spleen and is known as infiltrating splenomegaly (Chapman \& Azevedo, 2019). Splenomegaly was found in $87.9 \%$ of the sample. These results were not much different from research conducted at the Sanglah Hospital, Bali, Indonesia, where $96.6 \%$ of patients experienced splenomegaly (Kartawan et al., 2016). However, both of these results were much higher than what Jabbour et al got where the splenomegaly presence was $40-50 \%$ of all CML cases (Jabbour \& Kantarjian, 2018). In a study conducted at Cipto Mangunkusumo Hospital, Jakarta, Indonesia, the presence of splenomegaly was also much lower at $33 \%$ of the sample, although there were samples that had received therapy in the study (Reksodiputro et al., 2010). If evaluated through imaging, the spleen appearance is not specific and looks similar to lymphoma (Sjoberg et al., 2018). 


\section{Complete blood counts}

In this study, all samples had high leukocyte counts with an average of $254.58 \times 10^{3} / \mu \mathrm{L}$ and a median of $224.9 \times 10^{3} / \mu \mathrm{L}$. These results were in line with other studies with samples that had never been given therapy, one of which was a research conducted in Algeria. In that study, a high leukocyte count was found with a median of $346 \times 10^{3} / \mu \mathrm{L}$ (Entasoltan et al., 2017). Much lower results were obtained in other studies with samples that had received therapy, such as interferon, hydroxyurea, or tyrosine kinase inhibitors (Reksodiputro et al., 2010). Whereas, the mean and median sequences were $557 \times 10^{3} / \mu \mathrm{L}$ and $494 \times 10^{3} / \mu \mathrm{L}$ for platelet counts. Similar results were obtained in a study conducted at the Sanglah Hospital, Bali, Indonesia, where the average platelet count was $507.7 \times 10^{3} / \mu \mathrm{L}$ and $392 \times 10^{3} / \mu \mathrm{L}$. Whereas, the mean and median sequences were $557 \times 10^{3} / \mu \mathrm{L}$ and $494 \times 10^{3} / \mu \mathrm{L}$ for platelet counts. Similar results were obtained in a study conducted at the Sanglah Hospital, Bali, Indonesia, where the average platelet count is $507.7 \times 10^{3} / \mu \mathrm{L}$ and $392 \times 10^{3} / \mu \mathrm{L}$ (Kartawan et al., 2016), which indicated that platelet count tended to increase in CML cases. This statement was strengthened by the presence of $54.5 \%$ of patients who had thrombocytosis in this study and as many as $61 \%$ of patients in a study that had been conducted in several hospitals in Indonesia (Reksodiputro et al., 2010). Besides, CML patients tended to be anemic, were in this study, the mean and median hemoglobin sequences were $9.55 \mathrm{~g} / \mathrm{dL}$ and $9.3 \mathrm{~g} / \mathrm{dL}$, respectively, with $90.9 \%$ of patients experiencing anemia. Anemia that occurred was mostly in grade 2 (moderate), which was in $45.5 \%$ of the sample. This is matched with research conducted in Pakistan, where all patients had anemia, and grade 2 anemia was the most common in $46.9 \%$ of patients (Chang et al., 2015).

\section{Peripheral blood smear}

In this study, the profile of erythrocytes was dominantly normochromic normocytic with anisopoikilocytosis, the profile of leukocytes increased, and as much as $51.5 \%$ of the patients had the profile of an increase in platelets and 33.3\% of patients had giant platelets. The profile of erythrocytes and leukocytes in similar with studies that had been conducted at the Dr. Mohammad Hoesin Hospital, Palembang, Indonesia, where it was found that anemia that occurs in CML cases was mostly normochromic normocytic anemia and also supported by studies conducted in Pakistan. Even so, slightly different results were obtained on the profile of platelets, which was found in the research at the Dr. Mohammad Hoesin Hospital, Palembang, Indonesia, where the profile of the platelets tended to be regular with the presence of giant platelets in only $4.7 \%$ of the samples (Rahadiyanto et al., 2014; Chang et al., 2015). However, this research was still in line with the results obtained in the research at Dr. M Djamil Hospital, Padang, Indonesia, where the profile of platelets tended to increase in CML patients (Rendra et al., 2013). The study also found an increase in the percentage of basophils in $84.8 \%$ of patients with a median of $4 \%$ and an increase in the percentage of eosinophils in $21.2 \%$ of patients with a median of $3 \%$. The different results were found in the studies that have been conducted at the Dr. M. Djamil Hospital, Padang, Indonesia, where patients with an increase in the percentage of eosinophils are more numerous than basophils. In that study, the increase in the percentage of eosinophils and basophils, respectively, was $31.25 \%$ and $6.25 \%$ of the sample (Rendra et al., 2013). Even so, the median percentage of basophils is still in line with research conducted in Algeria, where the median percentage of basophils is 3.7\% (Entasoltan et al., 2017). Blast presence was almost always obtained (97\%), where $39.4 \%$ of patients had a blast percentage below $5 \%, 12.1 \%$ had a percentage in the range of $5-10 \%$, and $45.5 \%$ of patients had a percentage of more than $10 \%$. Different results were obtained in the epidemiological study of CML conducted in several hospitals in Indonesia, where 64\% of patients had a blast percentage below $5 \%$, and only $12 \%$ of patients had a percentage of more than $10 \%$. This indicated that the ratio of the chronic phase compared to other phases was smaller in this study than the study of Reksodiputro et al. (2010).

\section{CONCLUSION}

This study found that CML was more common in men (1.06:1) with a median age of 40 years and had the highest incidence at a younger age range. All CML patients who had not received therapy had high leukocytosis with an average of $254.58 \times 10^{3} / \mu \mathrm{L}$ and had a tendency to develop grade 2 anemia $(45.5 \%)$ with an average of $9.55 \mathrm{~g} / \mathrm{dL}$ and thrombocytosis (54.5\%) with an average of $557 \times 10^{3} / \mu \mathrm{L}$. Peripheral blood smear was dominated by normochromic normocytic erythrocytes with variations in shape and size (anisopoikilocytosis), increase in the number of leukocytes with various stages of 
maturation, and increase in the percentage of basophils in the majority of patients $(84.8 \%)$. Blast presence was found in almost all patients $(97 \%)$ and there was a tendency for increased platelets in which $33.3 \%$ of patients had giant platelets.

\section{REFERENCES}

Atul, B.M. Hoffbrand, A.V., 2014. Haematology at a glance. London: Blackwell Sciences.

Chang, F., Qazi, R.A., Khan, M., Baloch, S., Sahito, M.M., Mir, A., 2015. Clinico hematological profile and phase distribution of chronic myeloid leukemia. Biology and Medicine, 7(5): 5-8.

Chapman, J., Azevedo, A.M., 2019. Splenomegaly. [e-book] Treasure Island: StatPearls Publishing. Downloaded 27 November 2019 from https://www.ncbi.nlm.nih.gov/books/N BK430907

Entasoltan, B., et al., 2017. Outcome of frontline treatment with "generic" Imatinib in adult patients with chronic myeloid leukemia in Algerian Population: A multicenter study. Mediterranean Journal of Hematology and Infectious Diseases, 9(1): 6-11.

Fentie, A.M., Tadesse, F., Engidawork, E., Gebremedhin, A., 2019. Prevalence and determinants of nonadherence to Imatinib in the first 3-months treatment among newly diagnosed Ethiopian's with chronic myeloid leukemia. PLoS ONE, 14(3): 1-12.

Höglund, M., Sandin, F., Simonsson, B., 2015. Epidemiology of chronic myeloid leukaemia: an update. Annals of Hematology, 94(2): 241-247.

Howlander, N., Noone, A.M., Krapcho, M., Miller, D., Brest, A., Yu, M., Ruhl, J., Tatalovich, Z., Cancer Stat Facts: Leukemia - Chronic Myeloid Leukemia (CML). Downloaded from https://seer.cancer.gov/statfacts/html/cmyl.html

Jabbour, E., Kantarjian, H., 2018. Chronic myeloid leukemia: 2018 update on diagnosis, therapy and monitoring. American Journal of Hematology, 93(3): 442-59.

Kartawan, G., Suega, K., Rena, R., 2016. Karakteristik klinis pasien chronic myeloid leukemia dengan terapi tyrosine kinase inhibitor di Rumah Sakit Umum Pusat Sanglah [Clinical characteristics of chronic myeloid leukemic patients with tyrosine kinase inhibitor therapy in Sanglah Hospital]. EJurnal Medika Udayana, 4(9).

Ministry of Health, Repubic of Indonesia, 2013. Riset Kesehatan Dasar 2013 [Basic Health Research 2013]. Jakarta: Kementrian Kesehatan RI.

O’Brien, S., Vose, J., Kantarjian, H., 2011. Management of hematologic malignancies. Cambridge: Cambridge University Press.

Radivoyevitch, T., Jankovic, G.M., Tiu, R.V., Saunthararajah, Y., Jackson, R.C., Hlatky, L.R., Gale, R.P., Sachs, R.K., 2014. Sex differences in the incidence of chronic myeloid leukemia, Radiation and Environmental Biophysics, 53(1): 55-63.

Rahadiyanto, K.., Liana, P., Indriani, B., 2014. Pola gambaran darah tepi pada penderita leukimia di laboratorium klinik RSUP Dr. Mohammad Hoesin Palembang [Peripheral blood profile in leukemic patients at clinical laboratory of Dr. Mohammad Hoesin Hospital, Palembang]. Majalah Kedokteran Sriwijaya, 46(4): 259-65.

Raharjo, B., 2018. Hubungan kadar betha2 mikroglobulin serum terhadap rasio BCR-ABL pada pasien leukemia granulositik kronik (LGK) dengan terapi tyrosin kinase inhibitor [Correlation of serum microglobulin betha2 level on BCR-ABL ration in chronic granulocytic leukemia patients receiving tyrosin kinase inhibitor therapy]. Thesis. Surabaya: Universitas Airlangga.

Reksodiputro, A.H., Syafei, S., Prayogo, N., Karsono, B., Rinaldi, I., Rajabto, W., Mulansari, N.A., 2010. Clinical characteristics and hematologic responses to Imatinib in patients with chronic phase myeloid leukemia (CML) at Cipto Mangunkusumo Hospital. Acta Medica Indonesiana, 42(1): 2-5.

Rendra, M., Yaswir, R., Hanif., A. M., 2013. Gambaran laboratorium leukemia kronik di bagian Penyakit Dalam RSUP Dr. M. Djamil Padang [Chronic leukemia laboratory profile at Internal Medicine Department, M Djamil Hospital, Padang]. Jurnal Kesehatan Andalas, 2(3): 141-5.

Rohrbacher, M. \& Hasford, J., 2013. Etiology and epidemiology of chronic myeloid leukemia. In: Wiernik P., Goldman J., Dutcher J., Kyle R. (eds) Neoplastic diseases of the blood, New York: Springer.

Shah, N.P., Arceci, R.J., 2014. Chronic myeloid leukemia. New York: Bristol- Myers Squibb.

Sjoberg, B.P., Menias, C.O., Lubner, M.G., Mellnick, V.M., Pickhardt, P.J., 2018. Splenomegaly: a combined clinical and radiologic approach to the differential diagnosis. Gastroenterology Clinics of North America, 47(3): 643-66. 
Sumantri, A. F., Oehadian, A., Wijaya, I., Vidyaniati, P., Rahmaniati, R., 2019. Therapeutic responses of imatinib and nilotinib among CML patients in Hasan Sadikin Hospital Bandung. Indonesian Journal of Cancer, 12(3): 88. 